\title{
Grzech relacji homoseksualnych w Piśmie Świętym. Medialne oskarżenia a rzeczywiste przesłanie dokumentu Papieskiej Komisji Biblijnej "Czym jest człowiek? (Ps 8,5)”. Zarys antropologii biblijnej (2019)
}

\author{
The Sin of Homosexual Relations in the Sacred Scripture. \\ Media Accusations and Real Message of the Pontifical Biblical Commission's \\ "What is Man?" (Ps 8:5). An Itinerary of Biblical Anthropology (2019)
}

\section{HENRYK WITCZYK}

Katolicki Uniwersytet Lubelski Jana Pawła II

henwit@kul.lublin.pl, ORCID: 0000-0003-4451-0697

\begin{abstract}
Streszczenie: Natychmiast po ogłoszeniu w dniu 16 grudnia 2019 roku dokumentu Papieskiej Komisji Biblijnej „Czym jest człowiek? (Ps 8,5). Zarys antropologii biblijnej w wielu mediach dokonano manipulacji dotyczącej jego treści. Autor artykułu przedstawia na wybranych przykładach zaczerpniętych z prasy i portali internetowych, na czym polegała ta nierzetelna i wprowadzająca w błąd prezentacja. Ponieważ wypływa ona w dużej mierze z powierzchownej i wycinkowej lektury dokumentu, autor artykułu przedstawił jego, wbrew zarzutom, bardzo bogatą pod względem treści, aczkolwiek z uwagi na gatunek literacki tego rodzaju publikacji, syntetycznie zaprezentowaną katolicką wykładnię głównych tekstów Pisma Świętego, które mówią o żeńskich i męskich relacjach homoseksualnych (Rdz 19; Sdz 19; Kpł 18,22 i 20,13; Rz 1,26-28; 1 Kor 6,9-10; $1 \mathrm{Tm}$ 1,9-10). Autor dochodzi do wniosku, że Papieska Komisja Biblijna obiektywnie odczytała zawartą w nich ocenę tych aktów jako sprzecznych z planem (celowością) stworzenia (Rdz 1,26-28), z objawionym Prawem Bożym (Kpł 18,22 i 20,13) i prawdą wpisaną w naturę stworzeń (Rz 1,26-27), a także z chrystologią, pneumatologią i eklezjologią Nowego Testamentu (1 Kor 6,9-10; 1 Tm 1,9-10).
\end{abstract}

Słowa klucze: dokument Papieskiej Komisji Biblijnej (2019), homoseksualizm, celowość stworzenia, porządek stworzenia, „ciało dla Pana”

Abstract: On December 16, 2019, the Pontifical Biblical Commission released a document entitled What is man? (Ps 8:5). A Journey through Biblical Anthropology. Almost immediately, many media sources began misrepresenting its content, their misstatements stemming largely from a superficial and fragmentary reading of the work. However, the document is rich in content that deserves an honest hearing. Therefore, the present article has two main aims. First, it seeks to present and critically evaluate the media commentaries dealing with the document. Secondly, taking into consideration the literary genre of this type of pontifical publication, the article synthetically presents the Catholic interpretation of the main texts in Scripture that speak of female and male homosexual relationships (Gen 19; Judg 19; Lev 18:22 and 20:13; 1 Cor 6:9-10; 1 Tim 1:9-10; and Rom 1: 26-28). The author concludes that the Pontifical Biblical Commission has objectively interpreted the biblical assessment of these 


\section{HENRYK WITCZYK}

acts as being antithetical to revealed truth, along multiple dimensions: the plan (teleology) of creation (Gen 1:26-28); the revealed law of God (Lev 18:22 and 20:13); the truth inscribed within the nature of creatures (Rom 1:26-27); and the Christology, pneumatology and ecclesiology present in the New Testament (1 Cor 6:9-10; 1 Tim 1:9-10).

Keywords: Pontifical Biblical Commission's Document (2019), homosexuality, teleology of creation, order of creation, "body for the Lord"

W dniu 17 grudnia 2019 roku we włoskim dzienniku La Repubblica ukazał się komentarz do kilku wyrwanych z kontekstu zdań dokumentu Papieskiej Komisji Biblijnej Czym jest człowiek?1, ogłoszonego i zaprezentowanego papieżowi Francisz-

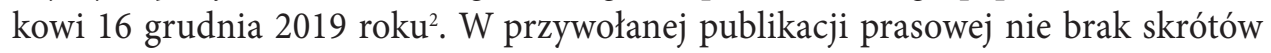
myślowych, przemilczeń i nadinterpretacji. Komentarz ten jest w istocie misterną manipulacją. Ten włoski tekst stał się podstawą dla polskiego komentarza na łamach portalu Breviarium Historiæ Ecclesiæ Postconciliaris, który już 19 grudnia 2019 roku przypisał Papieskiej Komisji Biblijnej „rozpoczęcie walki o afirmację homoseksualizmu i związków jednopłciowych”, z pogardliwym tagiem: „Pontyfikalna Komisja Biblijna wydała kolejnego gniota"3, chociaż komentowany tekst we włoskiej La Repubblica jest w tytule bardziej stonowany: „Kościół prosi o większą troskę duszpasterską nad związkami homoseksualnymi”. Trzeba przyznać, że włoski tytuł, jakkolwiek mało precyzyjny, przynajmniej nie przekręca - i to o 180 stopni - zasadniczego przesłania Dokumentu Papieskiej Komisji Biblijnej, jak czyni to wspomniany wyżej polski portal związany z „Kościołem posoborowym”. Równie nierzetelna i pełna nieuzasadnionych oskarżeń była kolejna polska internetowa prezentacja dokumentu, a mianowicie artykuł Marcina Jendrzejczaka na portalu PCh24.pl, nosząca alarmujący tytuł: „Sodoma spłonęła przez niegościnność? A co z homoseksualizmem? Analiza", opublikowana 22 grudnia $2019 \mathrm{roku}^{4}$. W poniższym artykule szukamy odpowiedzi na pytanie: Na czym polega manipulacja dokonywana w prezentacji dokumentu na łamach La Repubblica oraz na portalach Breviarium Ecclesiae Postconciliaris i PCh24.pl?

1 „Che cos’e l’uomo?” (Sal 8,5). Itinerario antropologico; tł. polskie: „Czym jest człowiek?”. Zarys antropologii biblijnej.

2 Pełny tekst komentarza zob.: „La Chiesa chiede «attenzione pastorale» alle unioni omosessuali”.

3 Zob. http://breviarium.blogspot.com/2019/12/papieska-komisja-biblijna-rozpoczyna.html [dostęp: 27.05.2021].

4 Zob. https://pch24.pl/sodoma-splonela-przez-niegoscinnosc-a-co-z-homoseksualizmem-analiza/ [dostęp: 27.05.2021]. 


\section{Relatywizacja głównej prawdy Biblii o małżeństwie przez jej fałszywe obramowanie kontekstowe}

Pierwszym zafałszowaniem jest wypaczenie sensu zasadniczego passusu: „instytucja małżeństwa, ustanowiona przez stabilny związek między mężem i żoną, jest stale przedstawiana jako oczywista i normatywna w całej tradycji biblijnej" (nr 185) wyrażającego podstawową i niezmienną prawdę o małżeństwie, która opiera się na dwóch biblijnych opisach stworzenia mężczyzny i kobiety (Rdz 1,26-28; 2,28-25); w Biblii nie ma też „przykładów legalnie uznanego związku między osobami tej samej płci" (nr 185) ${ }^{6}$. Deformacja tego przesłania Biblii w komentarzu zamieszczonym na łamach La Repubblica dokonana została poprzez obramowanie go z jednej strony napisanym dużymi literami tytułem: „Kościół prosi o troskę duszpasterską o związki homoseksualne", będącym kluczem dla interpretacji. Tymczasem w przytoczonym tekście dokumentu Papieska Komisja Biblijna wyraźnie i bez najmniejszego cienia wątpliwości stwierdza, że Pismo Święte nie podaje „przykładów legalnie uznanego związku między osobami tej samej płci” (nr 185). Co to znaczy? Otóż Objawienie w sposób ciągły i bardzo wyraźny mówi o małżeństwie jako związku mężczyzny i kobiety, których łączy sam Bóg Stworzyciel i im błogosławi, a Jezus Chrystus tę więź ustanawia sakramentem, czyli czyni wspólne życie małżonków drogą wiodącą do zbawienia i rozwinięcia w pełni tego talentu, którym jest bycie mężczyzną i bycie kobietą. Jeżeli Objawienie nie podaje przykładu żadnego „legalnie uznanego związku między osobami tej samej płci”, to znaczy, że takie związki nie są zgodne z Prawem Boga (Torą), czyli z Jego wolą jako Stworzyciela, a w Nowym Testamencie z Ewangelią Jezusa Chrystusa jako Zbawiciela.

5 Janusz Lemański („Człowiek jako mężczyzna i kobieta”, 97-118), komentując pierwszy opisy stworzenia człowieka (Rdz 1,26-28), podkreśla różnicę biologiczną i wręcz fizjologiczną między mężczyzną i kobietą, mocno zaznaczoną w tekście oryginalnym w Rdz 1,27: „W istocie tradycja P stosuje dwa «pojęcia biologiczne» określające fizjonomicznie aspekt męskości (zākār) i kobiecości (neqēbâa). Zwyczajowe tłumaczenie «mężczyzną i kobietą» stanowi raczej praktyczne rozwinięcie obu pojęć. Takie płciowe rozróżnienie odnosi się zarówno do człowieka (jeszcze w Rdz 5,2), jak i do zwierząt (Rdz 6,19; 7,3.9.16). Choć więc niewątpliwie P ma tu zapewne także na uwadze społeczne zróżnicowanie płci (ang. gender), to jednak w pierwszym i podstawowym znaczeniu obu użytych terminów - i to należy podkreślić - $\mathrm{P}$ [autor kapłański] akcentuje przede wszystkim różnice biologiczne i fizjonomiczne. Człowiek został stworzony zatem jako egzemplarz męski i żeński”.

6 W najnowszych komentarzach i artykułach poświęconych opisom stworzenia człowieka w Rdz 1,26-30 i w Rdz 2,18-25 podkreśla się, że „człowiek” (jako gatunek) został stworzony jako mężczyzna i kobieta. Podwójny rodzaj płciowy rodzaju ludzkiego jest akcentowany zarówno w aspekcie biologicznym, religijnym (por. $\operatorname{Rdz} 1,26-28)$, jak i społecznym (Rdz 2,18-25). Obydwie płci są uznawane za równe sobie w każdym z tym wymiarów. Ludzie w pełni realizują swe powołanie do życia i współpracy z Bogiem tylko jako mężczyzna i jako kobieta - powołani do życia w monogamicznym małżeństwie otwartym na prokreację. Jedynie w takim związku człowiek jest w stanie panować nad światem w sposób godny obrazu Boga, który nosi w sobie jako istota żyjąca w płodnej relacji: mężczyzna - kobieta. Por. Janowski, „Die lebendige Statue Gottes", 183-214. 
Z drugiej strony manipulacja dopełnia się przez to, że w komentarzu La Repubblica cytowany wyżej tekst dokumentu Czym jest człowiek? otoczony jest informacją, że „Papieska Komisja Biblijna zauważa jednak również głosy, które nie zgadzają się i domagają się akceptacji - na równi z akceptacją dla związków heteroseksualnych homoseksualizmu i związków homoseksualnych jako prawowitego i godnego wyrazu człowieczeństwa". Nie pisze się wyraźnie, że nie są to głosy członków Papieskiej Komisji Biblijnej, a komentator nie zadał sobie trudu, aby to doprecyzować. Zestawienie tych głosów z cytowaną wyżej podstawową tezą dokumentu wyraźnie relatywizuje jego treść, a zwłaszcza przedstawiony w nim stwórczy (pochodzący od Boga Stworzyciela) i odkupieńczy (pochodzący od Chrystusa), nienaruszalny i ponadczasowy charakter małżeństwa jako nierozerwalnego związku jednego mężczyzny i jednej kobiety, wpisanego nieodwołalnie w historię zbawienia?

Właściwym kontekstem dla prawdy o małżeństwie w Biblii - podanym w dokumencie - jest wprowadzenie do tej problematyki ujętej w paragrafie pod znamiennym tytułem: „Związek małżeński w historii ludzkości: problemy, normy, wykroczenia”. W punkcie nr 171 czytamy, że:

perspektywa antropologiczna, którą propaguje Biblia, uznaje w miłosnym związku mężczyzny i kobiety realizację projektu, który chce dla człowieka Stwórca (Rdz 1-2). Stałe i jednomyślne docenianie relacji małżeńskiej, z jej ukoronowaniem w postaci prokreacji i wychowania dzieci, staje się podstawowym elementem etycznych i religijnych ram tekstu natchnionego.

Ale równocześnie, jako zagrożenie dla tego kreacyjnego modelu związku małżeńskiego, dokument Czym jest człowiek? przywołuje te stronice Biblii, które uwidaczniają, jak na przestrzeni wieków ludzie go wypaczali poprzez „niewłaściwe podejścia i transgresywne zachowania, które wykoślawiają doskonałą formę związku małżeńskiego zaplanowaną przez Boga (modalità improprie e comportamenti trasgressivi che deturpano la forma perfetta dell'unione sponsale predisposta da Dio)". Następnie wskazuje się w dokumencie na różne przyczyny tych wypaczeń: czynniki natury ekonomicznej i prestiżu społecznego, wpływ kultur inspirowanych bałwochwalczymi kultami płodności, czy wręcz „żądze ludzkiego serca tak łatwo skłaniającego się ku głupocie i przemocy”. Jednak zapisana w Biblii historia zbawienia i Bożej pedagogii „prowadzi do stopniowej, ale zarazem ostatecznej afirmacji związku mężczyzny i kobiety jako jedynego modelu „związku” małżeńskiego. Jednocześnie, w kontraście

7 Por. Gross, „Gen 1,26.27”, 11-38; Neumann-Gorsolke, Herrschen in den Grenzen der Schöpfung; Napora, „Odpowiednia dla niego pomoc?”, 33-48; Napora, „'Wąż', ‘życie', czy ‘matka wszystkiego, co żyje'?”, 15-27. 
do niego, z rosnącą surowością Biblia wyraża potępienie praktyk transgresywnych (w sferze seksualnej) sprzecznych z prawem Bożym" (nr 171).

\section{Próba przypisania Papieskiej Komisji Biblijnej opinii przez nią cytowanych, z którymi się nie zgadza}

Manipulacją jest kolejny fragment komentarza w La Repubblica, w którym przypisuje się Papieskiej Komisji Biblijnej, niemal jako jej własne, te opinie, które ona jedynie referuje, odnotowując rzetelnie to, co w publicznej debacie na temat homoseksualizmu pojawia się jako roszczenie.

Nie przeszkadza to autorowi komentarza czynić podobnych sugestii, nawet w odniesieniu do wyraźnie brzmiącego zdania, które jest wprowadzeniem do prezentacji tych poglądów, z którymi Biblia, a co za tym idzie także Papieska Komisja Biblijna, się nie zgadza.

A brzmi ono: „Od jakiegoś czasu, zwłaszcza w kulturze zachodniej, ujawniły się głosy sprzeciwu (dissenso) względem poglądów antropologicznych zawartych w Piśmie Świętym, tak jak one są rozumiane i przekazywane przez Kościół w ich normatywnym znaczeniu” (nr 185). Natomiast w komentarzu dziennika La Repubblica czytamy dosadne stwierdzenie, że „Papieska Komisja Biblijna zauważa jednak również głosy sprzeciwu, które domagają się akceptacji - na równi z akceptacją dla związków heteroseksualnych - homoseksualizmu i związków homoseksualnych jako prawowitego i godnego wyrazu człowieczeństwa”. Pominięto informację o tym, że są to głosy, które nie ujawniły się w łonie Papieskiej Komisji Biblijnej, ale „zwłaszcza w zachodniej kulturze", komisja zaś stanowczo z nimi polemizuje. Już we wprowadzeniu do całego paragrafu - o znamiennym brzmieniu „zachowania transgresywne” (modalità trasgressive) - podaje w odniesieniu do związku małżeńskiego (nr 181-195) bardzo

8 Por. Fredrickson, „Natural and Unnatural Use in Romans 1:24-27”, 197-222. Trudno zgodzić się z interpretacjami tych autorów, którzy natchnione teksty Biblii, krytycznie osądzające praktyki homoseksualne ( $\operatorname{Rdz}$ 9,20-27; 19,1-11; Kpł 18,22; 20,13; Rz 1,26-27; 1 Kor 6,9-10; 1Tm 1,10), relatywizują, twierdząc, że odnoszą się one do starożytnych praktyk kultowych, a nie do współczesnej kondycji i samoświadomości ludzi, którzy praktykują relacje seksualne z osobami tej samej płci. Zob. Esler, „The Sodom Tradition in Romans 1:18-32”, 4-16; White, „Does the Bible Speak about Gays or Same-Sex Orientation?”, 14-23; Gnuse, „Seven Gay Texts”, 68-87. Miałkość i nieadekwatny charakter przywoływanych w powyższych artykułach argumentów, które dekonstruują lub odrzucają Pawłową i biblijną krytykę postaw homoseksualnych, wykazuje Marcin Kowalski („Odrzucenie praw Stwórcy”, 255-280), który ich pozycje podzielił na trzy kategorie: argumenty z pozycji współczesnej psychologii i starożytnych praktyk homoseksualnych (także kultowych), argumenty z rozumienia natury u Pawła oraz argumenty z kontekstu retoryczno-literackiego Rz 1,18-32. Autor krytycznie ustosunkowuje się do wymienionych argumentów, wskazując także na ich anachroniczność, błędne zawężenie kontekstu argumentacyjnego apostoła, nieuprawnione zrównanie pojęcia natury z normą kulturową oraz zlekceważenie uniwersalistycznego charakteru Pawłowego dyskursu w Rz 1,18-32. 
ważny klucz interpretacyjny do takich wykroczeń przeciw objawionemu Prawu Bożemu, jak kazirodztwo, cudzołóstwo, prostytucja, homoseksualizm: „Pismo Święte nie tylko wspomina o problematycznych aspektach instytucji małżeństwa, ale potępia także postawy uwłaczające dobru, które będąc przeciwnymi woli Bożej, podlegają zatem (uważanym za) proporcjonalne karom" (nr 181). A konkludując passus, w którym przytoczone zostały roszczenia współczesnej kultury zachodniej dotyczące homoseksualizmu i związków homoseksualnych (nr 181 - otwierający większy fragment nt. homoseksualizmu, nr 181-195), stwierdza: „Wydaje się zatem koniecznym przebadanie fragmentów Pisma Świętego, w których porusza się problematykę homoseksualną, w szczególności tych, w których praktyki te są ganione i potępiane" (nr 185). Natychmiast należy podkreślić, że Biblia nie mówi o inklinacji erotycznej do osoby tej samej płci, a tylko o aktach homoseksualnych. Po tych słowach następuje szczegółowa analiza tekstów biblijnych Starego Testamentu (Rdz 19; Sdz 19; Kpł 18,22 i 20,13), dopełniona analizą najważniejszych w tej materii fragmentów ksiąg nowotestamentowych (Rz 1,26-27; 1 Kor 6,9-10 i 1 Tm 1,9-10)9.

\section{Odwrócona i zawężona interpretacja homoseksualizmu i „związków" homoseksualnych w tekście portalu PCh24.pl}

Na portalu PCh24.pl w dniu 22 grudnia 2019 r. ukazał się - wspomniany już wyżej artykuł Marcina Jendrzejczaka pod alarmującym tytułem: „Sodoma spłonęła przez niegościnność? A co z homoseksualizmem? [ANALIZA]”. Autor zadał sobie trud, aby przedstawić krytykę dokumentu Papieskiej Komisji Biblijnej, jaką zamieściła Diane Montagne na portalu lifesitenews.com (19.12.2019), popierając jej argumenty swoimi dopowiedzeniami ${ }^{10}$. Według tej autorki Papieska Komisja Biblijna sugeruje, że

9 Te i kilka innych tekstów Biblii, jako ganiące i potępiające akty homoseksualne, analizuje Marcin Kowalski („Honor i wstyd, prawo naturalne oraz Pisma”, 223-254) na tle starożytnej kultury, zasadzającej się na poczuciu honoru i wstydu. Na bazie bogatej literatury stwierdza, że kategorie honoru i wstydu były obowiązujące w świecie hellenistycznym. To do nich najpierw odwołuje się św. Paweł, opisując żeńskie i męskie relacje homoseksualne jako powodowane „haniebnymi namiętnościami” i rozpalonymi „żądzami”, a w konsekwencji prowadzące do „bezwstydu” (Rz 1,26-27). Następnie apostoł opiera się na prawie naturalnym, które pojmuje nie jako normę kulturową, ale - podobnie jak niektórzy autorzy grecko-rzymscy i żydowscy - jako porządek stworzenia przeniknięty Bożym zamysłem. I wreszcie podstawowym punktem odniesienia dla apostoła pozostają Pisma oraz szeroko pojęta tradycja żydowska (Kpł 18,22; 20,13; Pwt 4,16-19; Ps 105,20; Jr 2,11; Mdr 12-15), a zwłaszcza Rdz 1-3 (ze szczególnym naciskiem na Rdz 1,27-28). Wiążą one homoseksualizm z idolatrią, przekraczaniem porządku stworzenia i zacieraniem różnic płciowych między mężczyzną i kobietą. Różnice te służą prokreacji, ale także wzajemnemu zrozumieniu się i uzupełnianiu mężczyzny i kobiety. Por. także Klän, „Das Gesammtdasein Menschlichen Geschlechts", 91-105.

10 Montagne, „Vatican Publishes New Book Reducing 'Sin of Sodom' to 'Lack of Hospitality”. W podobnym duchu komentuje tekst inny portal fsspx.news, gdzie w omówieniu medialnych doniesień („Pontifical 
to nie homoseksualizm ściągnął na Sodomę karę Bożą. Jak pisze Montagne, według teologów komisji opisana w Księdze Rodzaju „historia nie służy jednak przedstawieniu wizerunku całego miasta zdominowanego przez niepohamowane homoseksualne żądze, lecz potępia postępowanie społecznych i politycznych instytucji niezamierzających witać przybysza z szacunkiem, upokarzających go [...]”. Cytując powyższy fragment, Marcin Jendrzejczak dopowiada doń: „Interpretację tę wspiera według autorów fragment Księgi Mądrości, wskazujący, że to właśnie nienawiść wobec przybyszy przyczyniła się do kary wymierzonej Sodomie i Egiptowi”. Cytując amerykańską autorkę, Jendrzejczak pisze również: „Komisja stosuje wedle dziennikarki «strategię retoryczną służącą przesunięciu obserwowanego (ang. perceived) nauczania Kościoła w kierunku radykalnej ideologii gender naszych dni, bez jednoczesnego dążenia do odrzucenia całego tego dystansu (dzielącego Kościół od genderyzmu - przyp. MJ) za jednym posunięciem»".

A dalej już Jendrzejczak stawia pytanie: „Czy jednak usprawiedliwione jest redukowanie grzechu sodomskiego do niegościnności?”. Powołując się na autorów książki W obronie wyższych praw, stwierdza:

Pogarda dla ubogich i przybyszów wpisuje się w grzech mieszkańców Sodomy - ten jednak nie sprowadza się wyłącznie do niego. Mieszkańcy ukaranego miasta dopuszczali się nie tylko jej. Popełniali nieprawość na najrozmaitsze możliwe sposoby. Wybitny egzegeta Korneliusz a Lapide (1567-1637) stwierdzał, że wśród rozlicznych grzechów, jakich dopuszczali się mieszkańcy Sodomy, znajdują się pycha, przesyt i obfitość, lenistwo i brak miłosierdzia. To właśnie niemiłosierna postawa wywołała w konsekwencji nienaturalne zachowania seksualne.

W każdym razie, jak twierdzą autorzy książki W obronie wyższych praw, ,jest zatem jasne, że chociaż mieszkańcy Sodomy dopuszczali się różnych wzajemnie ze sobą powiązanych grzechów, to grzechem, który sprowadził na nich karę Bożą, był homoseksualizm. Tak brzmi jednomyślna interpretacja Ojców Kościoła i wszystkich egzegetów pozostających w zgodzie z Tradycją" - wyrokuje M. Jendrzejczak ${ }^{11}$.

Kończąc swoje wywody, M. Jendrzejczak formułuje oskarżenie skierowane pod adresem Papieskiej Komisji Biblijnej, mające zdemaskować jej szkodliwe dla prawdy i Tradycji działanie:

Dążenia do zmiany tej narracji, do uwolnienia jej od kulturowego kontekstu czy głębszego wydobycia treści biblijnej stanowią raczej przejaw ulegania współczesnym modom

Biblical Commission Issues Gravely Confusing Study”) treść dokumentu oceniona jest jako „dangerous confusion".

11 Interpretacja Rdz 19,1-11 św. Augustyna, czołowego Ojca Kościoła na Zachodzie, zob. Jaśkiewicz, „Złe czyny mieszkańców Sodomy (Rdz 19,1-11)", 353-368. 


\section{HENRYK WITCZYK}

niż głębszego poznania Pisma. Rozmywanie przesłania biblijnej historii o Sodomie szkodzi koniec końców także samym grzesznikom, którym przykład zniszczonego miasta - dzięki swemu dramatyzmowi - służy za wezwanie do nawrócenia i szczęścia, którego Bóg pragnie dla wszystkich. Także dla zmagających się z problemem homoseksualizmu.

Ale czy rzeczywiście Papieska Komisja Biblijna zmienia narrację Rdz 19, rzekomo wskazując jedynie na niegościnność jako przyczynę zagłady Sodomy? Czy rozmywa przesłanie biblijnej historii o Sodomie? Czy rzeczywiście stosuje strategię retoryczną, służącą przesunięciu nauczania Kościoła w kierunku radykalnej ideologii gender naszych dni - jak na podstawie pobieżnej analizy jednego punktu autorytatywnie zawyrokowała D. Montagne? Aby rzetelnie odpowiedzieć na te oskarżenia, wykazać ich nietrafiony, jedynie powierzchownie i pozornie „uzasadniony” charakter, należy przeprowadzić szczegółową i wnikliwą analizę wszystkich fragmentów dokumentu Czym jest człowiek? (Ps 8,5) poświęconych homoseksualizmowi (nr 181-195).

Z analiz tekstów biblijnych dotyczących Sodomy (Rdz 19) i pokolenia Beniaminitów w Gaba (Sdz 19) wynika, że do bardzo ciężkiego grzechu braku otwartości na przybyszów (złamanie prawa gościnności, uznawane przez niektórych komentatorów rzeczywiście za jedyny grzech w tym fragmencie) dołącza się „śmiercionośna przemoc" seksualna (violenza mortifera), która podlega odpowiednio surowej karze (nr 188; dokument podaje także tę drugą interpretację). W tym drugim kluczu teksty te interpretował już Kościół apostolski, o czym świadczą przywołane w dokumencie Papieskiej Komisji Biblijnej teksty z 2 P 2,6-10 i Jud 7². W dokumencie Czym jest człowiek? czytamy, że w Rdz 19

miasto Sodoma jest obwiniane za nieprzyzwoitą praktykę seksualną, zwaną „sodomią”, polegającą na związkach natury erotycznej z osobami tej samej płci. W Rdz 19 mówi się o dwóch „aniołach” (w. 1), którzy nocowali w domu Lota, a którzy zostali otoczeni przez „mężczyzn z Sodomy” (w. 4), młodych i starych, całą społeczność, chcącą wykorzystać seksualnie tych cudzoziemców (w. 5). Użyty tu hebrajski czasownik to "poznać”, eufemizm relacji seksualnych, co potwierdza propozycja Lota, który w celu ochrony gości jest gotów poświęcić dwie córki, które jeszcze „nie po znały mężczyzny” (w. 8) (nr 186).

I chociaż - jak czytamy dalej w tymże dokumencie - na pierwszy plan w analizie Rdz 19 wysuwa się brak otwartości na przybyszów, to jednak kanoniczna reinterpre-

12 Stosunkowo wolną od tendencji ideologizujących według zasad poprawności politycznej analizę i syntezę najnowszych badań nad tymi dwiema perykopami podaje Dorota Muszytowska („Kwestia homoseksualizmu w Listach Powszechnych", 307-322). 
tacja tego tekstu w świetle 2 P 2,6-9 i Jud 7, gdzie ewidentnie wskazuje się na przemoc doświadczaną przez sprawiedliwego Lota, kazała w podsumowaniu stwierdzić, że:

opowiadanie ( $\mathrm{Rdz} 19)$ nie ma jednak na celu przedstawienia obrazu całego miasta zdominowanego przez nieokiełznane żądze natury homoseksualnej; potępia się raczej zachowanie podmiotu społecznego i politycznego, który nie chce z szacunkiem przyjąć obcego, zmierzając do poniżenia go, zmuszając go siłą do znoszenia odbierającej honor podległości (nr 187).

Jak widać praktyki homoseksualne łączone są z określonym „podmiotem społecznym i politycznym” (miasto), który nie dlatego nie toleruje „obcego”, bo jest przybyszem i szuka chleba, ale dlatego, że nie podziela panującego w nim modelu transgresywnych relacji. Co więcej, ta nietolerancja przechodzi w przemoc seksualną, zmierzającą do poniżenia i podeptania honoru i ludzkiej godności przybyszów ${ }^{13}$.

Jeszcze wyraźniej tę nietolerancję - tym razem zepsutego przez bałwochwalstwo pokolenia Beniamina - i poniżająco-agresywną, wręcz niosącą śmierć przemoc natury seksualnej, widać w Sdz 19. Ostatecznie zatem podana w dokumencie Czym jest człowiek? interpretacja Rdz 19 i Sdz 19 - łącząca element wrogości wobec obcych (głównie z uwagi na ich model życia małżeńskiego niedopuszczający relacji homoseksualnych) z dominującymi w zepsutym mieście (w jego kulturze) zachowaniami transgresywnymi, rozumianymi wręcz jako „śmiercionośna przemoc” depcząca honor i godność oraz nastająca na życie człowieka (i to gościa, który winien być specjalnie chroniony!) - jest dwakroć mocniejsza niż te interpretacje, które widzą $\mathrm{w}$ tych tekstach jedynie grzech sodomii lub tylko grzech braku gościnności.

A krytykowi dzielnie strzegącemu „jednomyślnej interpretacja Ojców Kościoła i wszystkich egzegetów pozostających w zgodzie z Tradycją” dokument Papieskiej Komisji Biblijnej (nr 186) przytacza nauczanie nie tylko Księgi Mądrości, ale i pro-

13 Szeroką panoramę interpretacji Rdz 9,1-12 prezentuje Krzysztof Napora („«Mieszkańcy Sodomy byli źli...» [Rdz 13,13]”, 119-136). Zob. także komentarze do Rdz 19,1-12, w których dostrzega się zło relacji homoseksualnych jako gwałcących święte prawo gościnności, a więc jako grzech wyjątkowo ciężki: Morschauser, „Hospitality’, Hostiles and Hostages”, 461-485; z kolei Simon Parker („The Hebrew Bible and Homosexuality", 4-19) przekonuje, że agresja mieszkańców Sodomy w odniesieniu do gości Lota miała ewidentnie charakter seksualny, ale zastrzega, że nie brali oni pod uwagę typowej dla współczesności klasyfikacji na orientacje seksualne, czyli nie miało dla nich znaczenia, czy to są mężczyźni. Temu jednak nie odpowiadają dane tekstowe: oni wyraźnie odrzucają propozycję Lota, że odda im swoje córki dziewice. Ostatecznie cały komentarz sprowadza się do wniosku, że dla Lota, źle traktującego swoje córki, ważniejsze było prawo gościnności niż moralne dobro rodziny. Tego rodzaju konkluzja każe ostatecznie stwierdzić, że Lot - postawiony w sytuacji dramatycznej bezsilności - postrzega gwałt w zakresie męskich relacji homoseksualnych (do tego w odniesieniu do niczemu niewinnych gości) za czyn gorszy niż nierząd z jego własnymi córkami; z kolei Ellen F. Davis („Reasoning with Scripture”, 516) twierdzi, że wspólnoty protestanckie nie mogą z jednej strony rozmazywać nauczania Biblii na temat świętości życia (por. Kpł 18,22; 20,13; Rdz 19,1-12), a z drugiej głosić najwyższy autorytet tejże Biblii w ich kościelnym życiu. 


\section{HENRYK WITCZYK}

roków. To nie dopiero Korneliusz a Lapide wyliczał inne grzechy Sodomy, ale czynili to już tacy prorocy, jak: Izajasz (zdrada Boga - 1,10; złe postępowanie - 3,9), Jeremiasz (cudzołóstwo, kłamstwo, złoczyńcy, brak nawrócenia - 23,14), Ezechiel („Oto taka była wina siostry twojej, Sodomy: ona i jej córki odznaczały się wyniosłością, zachłannością i spokojną beztroską, ale nie wspierały biednego i nieszczęśliwego, co więcej, uniosły się pychą i dopuszczały się tego, co wobec Mnie jest obrzydliwością"- 16,49-50; por. Syr 16,8). Jak widać znacząca tradycja prorocka używała nazwy Sodoma (i Gomora) jako emblematycznego, ale mającego szerokie znaczenie, tytułu określającego miasto niegodziwe, podłe i radykalnie zepsute (città malvagia; por. Pwt 32,32-34). Zanim się rzuci oskarżenie, należy jednak sięgnąć do pełnego tekstu dokumentu. Więcej, należy przeczytać te teksty Pisma Świętego, które są $\mathrm{w}$ nim przywołane jedynie w formie referencji (i bardzo skrótowo zasygnalizowane), jak w przypadku nauczania proroków o Sodomie.

Z kolei odnosząc się do tekstów Księgi Kapłańskiej $\left(18,22\right.$ i 20,13) ${ }^{14}$, będącej sercem Tory, według których akty homoseksualne winny być karane śmiercią, Papieska Komisja Biblijna stwierdza: „Nie mamy informacji, że kara ta była kiedykolwiek wykonana. Pozostaje jednak faktem, że takie działania są uważane za ciężkie przestępstwo w świetle Prawa starotestamentowego i są surowo zakazane" (nr 189). Co więcej, dodaje się, że jakkolwiek Prawodawca

nie podaje motywacji ani samego zakazu, ani surowej kary, to możemy twierdzić, że podana w Księdze Kapłańskiej norma ma na celu ochronę i promocję życia seksualnego otwartego na prokreację, w zgodzie z przykazaniem danym przez Stwórcę istotom ludzkim $(\mathrm{Rdz} 1,18)$, i troszcząc się naturalnie o to, żeby takie życie seksualne było wpisane w zgodny z Prawem model małżeństwa (nr 190).

O tej interpretacji i retoryce Papieskiej Komisji Biblijnej nie wspomina ani D. Montagne, ani M. Jendrzejczak.

Bez wątpienia najmocniejszym, nowym, podanym przez Papieską Komisję Biblijną argumentem, który ukazuje istotę zła „Związków” jednopłciowych, jest odniesienie ich do dzieła stworzenia, ujętego w Rdz 1,1-2,4a, oparte na schemacie „rozdzielania”, inaczej mówiąc, rozróżniania (diversità), na którym zasadza się cała logika dzieła stworzenia zawarta w stwórczym Słowie Boga. Poszczególne stworzenia powoływane są do istnienia parami w kolejne dni: dzień i noc; niebo i ziemia itd. Tak objawione w Rdz 1 „działanie stwórcze Słowa Boga znajduje swe zwieńczenie w rozróżnieniu między mężczyzną i kobietą (maschio e femina); a jego symboliczny walor zostaje zanegowany i zagrożony przez współżycie seksualne osób tej samej płci” (nr 190). W świetle tego stwierdzenia akty homoseksualne są nie tylko czynami

14 Teksty te wnikliwie analizuje Barbara Strzałkowska („Homoseksualizm w prawodawstwie biblijnego Izraela", 137-162). 
naruszającymi Dekalog jako Prawo Przymierza z Bogiem, ale czymś co neguje najbardziej podstawowe dobro, jakim jest samo dzieło Bożego stworzenia, a nawet mu zagraża. Czyny homoseksualne nie tylko są buntem względem Boga Stworzyciela, ale także aktami radykalnie destrukcyjnymi i niszczącymi najważniejszy wymiar Jego dzieła, jakim bez wątpienia jest płodność, dzięki której mężczyzna i kobieta przekazują życie nowym pokoleniom i mogą panować nad ziemią ${ }^{15}$. Całe dzieło stworzenia, ukoronowane takim dynamizmem współ-stwarzającym życie i na nim osadzone, sam Stwórca uznał za bardzo dobre, co autor natchniony podkreśla z retoryczną emfazą $(\operatorname{Rdz} 1,31)^{16}$.

\section{Przemilczane nauczanie św. Pawła - wnikliwie analizowane w dokumencie Papieskiej Komisji Biblijnej}

Apostoł Paweł kilka razy zabiera głos w sprawie homoseksualizmu. Jego nauczanie zostało wnikliwie przeanalizowane w dokumencie Czym jest człowiek? Niestety ani w artykule na łamach La Repubblica, ani w opracowaniu Marcina Jendrzejczaka na

15 Por. Twardziłowski, „The Command to Rule over the Creation”, 9-32. Autor, konkludując (s. 26) prezentację dawnych i najnowszych interpretacji Rdz 1,26-28 w odniesieniu do miejsca i roli człowieka w całym dziele stworzenia, podsumowuje badania kierunku zwanego neo-ortodoksyjnym słowami: „Supporters of the neo-orthodox current claim that the fragment of Gen 1:26-28 read in the context of Gen 1-9 does not motivate, let alone allow, any excessive or arbitrary exploitation of the world by humans, but constitutes a criticism of human behaviour towards creation, and of the evil which lies at its foundation. In their opinion, God's command in Genesis 1:26-28 for man to rule over creation has a prophetic character and appears as an ideal that should be pursued. It is an invitation to create a community capable of living in the Word according to God’s intention”. Por. Suchy, „Czyńcie sobie ziemię poddaną”, 13-23; Szymik, „"Czyńcie sobie ziemię poddaną» (Rdz 1,28)", 21-44.

16 Ocena „bardzo dobre” łączy się z faktem, że autor natchniony pierwszego opisu stworzenia przechodzi od wielości „gatunków” i „rodzajów” roślin oraz zwierząt (por. Rdz 1,11-12.21) do jednego gatunku, który otrzymuje godność stworzenia na „obraz Boży”, mającego panować nad pozostałymi stworzeniami i zaludniać ziemię dzięki ustanowionej przez Stwórcę jedynej różnicy (mężczyzna - kobieta) i ukierunkowaniu ich na prokreację poprzez monogamiczny i heteroseksualny związek (por. Rdz 1,26-28). Janusz Lemański („Człowiek jako mężczyzna i kobieta”, 106) trafnie zauważa, że różnica pod względem płci między mężczyzną i kobietą jest w istocie jedyną różnicą decydującą o rozwoju jednego gatunku „człowiek”, a nie np. dwóch, różnych pod względem gatunku ludzi. Pisze: „Człowiek - mężczyzna i kobieta - stanowią przedstawicieli wyłącznie jednego gatunku. Tylko on w swojej męskiej i żeńskiej wersji zasługuje na miano imago Dei i zawierzenie mu wspomnianych powyżej zadań. Także tylko to płciowe rozróżnienie ma tu też jakiekolwiek znaczenie w sposobie patrzenia na drugiego człowieka. Akcentuje się tym samym najpierw fakt, że jest ono wyrazem stwórczej woli Boga, a potem także, że stanowi ono uzdolnienie umożliwiające realizację zadania: bycie płodnym i zaludnienie ziemi (w. 28). Ma to potem dalsze konsekwencje. Płciowość stanowi jedyną istotną różnicę pomiędzy ludźmi. Wszystkie inne różnice: geograficzne, antropologiczne, etniczne, rasowe i kulturowe nie stanowią i stanowić nie mogą o większej lub mniejszej godności człowieka (por. Ga 3,28)”. 
portalu PCh24.pl nie zostało ono nawet wspomniane, poza jednym zdaniem o karze wpisanej w sam grzech.

Tymczasem św. Paweł - jak pisze Papieska Komisja Biblijna - zalicza stosunki homoseksualne (męskie i żeńskie) do grzechów ciężkich i umieszcza na listach przestępstw, które wykluczają człowieka z królestwa Bożego (1 Kor 6,9-10) ${ }^{17}$. Listy te są podobne do Dekalogu (Wj 20,1-17; Pwt 5,6-21) i innych starotestamentowych wykazów grzechów łamiących Przymierze z Bogiem (Kpł 18,22; 20,23; por. nr 191) ${ }^{18}$. Drugą listę grzechów (1 Tm 1,8-10) Paweł umieszcza w bardzo znaczącym kontekście, w którym mówi o czynach tak strasznych jak matko- czy ojcobójstwo, a zarazem uwodzicielskich, będących przeciwieństwem „Ewangelii chwały błogosławionego Boga” (1 Tm 1,11) ${ }^{19}$. Dla chrześcijan stosunki homoseksualne są grzechem ciężkim ${ }^{20}$. Dla św. Pawła nie ma znaczenia fakt, że poza wspólnotami chrześcijańskimi mogły w niektórych środowiskach starożytnego świata istnieć inne opinie, jakkolwiek i w nich bardzo ważną rolę odgrywały takie wartości moralne, jak honor i wstyd. Akty homoseksualne są według Apostoła Narodów czynami sprzecznymi z prawdą o Bogu Stwórcy i stworzeniu oraz poważnie łamią Prawo Boże zakorzenione w Przymierzu (por. nr 192) ${ }^{21}$. Co więcej, z kontekstu, w którym św. Paweł umieszcza te dwie listy grzechów, jasno wynika, że postawione w ich centrum grzechy homoseksualne zrywają jedność chrześcijanina, który się ich dopuszcza, z Kościołem i Chrystusem (1 Kor 6,12-20), łamią w istotny sposób Dekalog i są radykalnym zaprzeczeniem przykazania miłości (1 Tm 1,8-10;

17 Katalog ten nie jest jakimś obcym ciałem w Pierwszym Liście do Koryntian, rysującym do tego negatywny obraz życia chrześcijańskiego, ale doskonale wpisuje się w najbliższy kontekst (1 Kor 5,1-13 oraz 1 Kor 6,12-20), w którym św. Paweł zarysowuje podstawowe linie chrześcijańskiej etyki seksualnej. Syntetycznie streszcza ją M. Kowalski („Katalogi wad”, 281-306), pisząc: „Katalog wad w 1 Kor 6,9-10 wpisuje się w oryginalną etykę Pawłową, związaną z życiem w Chrystusie. Ciało ludzkie staje się w niej częścią Ciała Chrystusa i świątynią Ducha, służy oddawaniu czci Bogu. Tego chrystologicznego horyzontu nie było w Rz 1,26-27, gdzie argumentacja Pawła została oparta na możliwie szerokiej podstawie teologii stworzenia i prawa naturalnego, będąc ukierunkowaną także na pogan i Żydów”. Zob. także Bailey, „Paul's Theological Foundation for Human Sexuality", 27-41; Fee, The First Epistle to the Corinthians, 266-267.

18 Por. Malina - Pilch, Social-Science Commentary on the Letters of Paul, 83; Ciampa - Rosner, The First Letter to the Corinthians, 238.

19 W tym kontekście cudzołóstwo i relacje homoseksualne przyjmują szczególnie negatywne konotacje. Prócz Dekalogu wiążą się one w sposób oczywisty z Księgą Kapłańską. Por. Kowalski, „Katalogi wad”, 295-297.

20 W kontekście interpretacji relatywizujących ciężar tych grzechów poprzez ograniczanie szerokiego za-

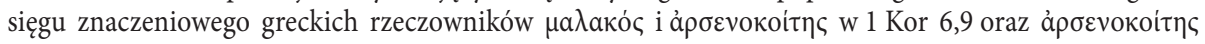
w $1 \mathrm{Tm}$ 1,10 do pederastii i prostytucji, a także poprzez odwoływanie się do nieaktualnych dzisiaj norm kulturowych, uniwersalne znaczenie tych słów, opisujących osoby praktykujące wszelkie akty homoseksualne, precyzyjnie wykazuje David F. Wright („Homosexuals or Prostitutes?”, 125-153; „Translating APऽENOKOITAI", 396-398).

21 Por. DeYoung, „The Meaning of 'Nature' in Romans 1”, 429-441; Springett, Homosexuality in History, 141; Himbaza - Schenker - Edart, The Bible on the Question of Homosexuality, 79-80; Yarbrough, The Letters to Timothy and Titus, 115-116. 
por. $1 \mathrm{Tm}$ 1,5; Rz 13,8-10; Kpł 19,18 ${ }^{22}$. Pawłowych list grzechów ciężkich nie można relatywizować, sprowadzając do norm dawnej kultury, albo przeciwstawiać tych czynów współczesnej wrażliwości jako niezrozumiałych i obraźliwych dla niej. Mają one bowiem ten sam walor uniwersalizmu co przykazania Dekalogu, prawo miłości Boga i bliźniego czy dokonane przez Jezusa odkupienie z niewoli grzechów, o którym mowa w ich bezpośrednim kontekście.

Nade wszystko jednak św. Paweł w obydwu katalogach wad łączy swoją etykę seksualną $\mathrm{z}$ chrystologią i pneumatologią. Najwyraźniej widać to w komentarzu do 1 Kor 6,9-10, w którym - posługując się obrazem monogamicznego i heteroseksualnego małżeństwa z Rdz 2,24 - stwierdza przynależność ochrzczonego człowieka i jego ludzkiego ciała (tworzącego cząstkę Kościoła - eklesia) do Pana i mówi o jego przyszłym zmartwychwstaniu mocą Ducha (1 Kor 6,13-14) ${ }^{23}$. Członki ciała wierzących są członkami ciała Chrystusa, nie można ich zatem używać do prostytuowania się ani uprawiania innych relacji, które zrywają więź z Panem (1 Kor 6,15-16). Chrześcijanin włączony w ciało Chrystusa, zjednoczony z Panem, jest z Nim jedno Duchem, który przenikając ciało Chrystusa i ciało wierzącego, spaja je w jeden organizm (1 Kor 6,17). Grzeszący wykroczeniami natury seksualnej, grzeszy przeciw własnemu ciału, które nie jest już tylko jego ciałem (1 Kor 6,18). Jest mieszkaniem Ducha Świętego, którego chrześcijanie otrzymują na zasadzie więzi z Bogiem i Chrystusem (1 Kor 6,19). Odkupienie ciała i całego człowieka, nabyte za wielką cenę krwi Chrystusowej, sprawia, że wierzący winni żyć jak On - w duchu miłości ofiarnej, zwyciężającej grzech i służącej życiu, a ostatecznie budującej Ciało Chrystusa poprzez rodzenie nowych wierzących w Niego.

Najobszerniej problem aktów homoseksualnych oraz osób dopuszczających się tych czynów św. Paweł przedstawia w Rz 1,18-32, gdzie denuncjuje homoseksualizm jako ciężki grzech przeciw najwyższej wartości świata judaizmu, czyli Prawu Bożemu

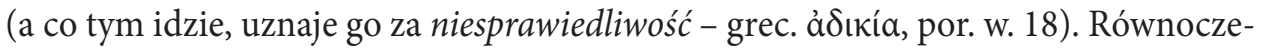
śnie widzi w nim grzech przeciw Prawdzie, która była najwyższą wartością w świecie greckim. Dlatego uznaje go za głupotę ( $\mu \omega \rho$ pív $\omega)$ i fałsz ( $\psi \varepsilon \tilde{\delta} \delta$ oc) (por. w. 21-22.25),

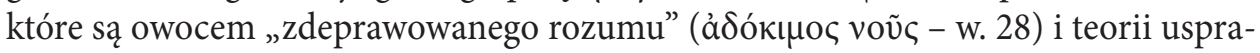
wiedliwiających zło (w. 32). Apostoł dostrzega i w mocnych słowach opisuje powszechne zepsucie człowieka żyjącego w świecie po grzechu Adama (1,18-32), ale wskazuje też, że Bóg odpowiada na nie, otwierając przed wszystkimi ludźmi - tak przed Żydami mającymi Prawo, jak i przed Grekami szukającymi Prawdy - jedyną drogę usprawiedliwienia: przez wiarę w Jego Syna (Rz 3,21-26). Również w kontekście Rz 1,18-32 punktem odniesienia Pawłowego nauczania o grzechach ludzi oraz ich przezwyciężeniu jest chrystologia, a dokładniej mówiąc Chrystus i Jego Ofiara

\footnotetext{
22 Por. Towner, The Letters to Timothy and Titus, 129.

23 Zob. May, The Body for the Lord, 89-145.
} 
dająca moc przemiany grzeszników w sprawiedliwych (posłusznych woli i mądrości Boga $)^{24}$. Paweł przedstawia szerzący się w ludzkim świecie grzech (Rz 1,19-32), w tym także żeńskie i męskie relacje natury homoseksualnej, jako dynamizm radykalnie destrukcyjny i niszczący dzieło stworzenia. Według apostoła wiąże się on ściśle z zakwestionowaniem Bożego porządku stworzenia i pozycji Boga jako Stwórcy i wynika z ubóstwienia świata stworzonego i obraca się przeciw człowiekowi, skutkując zbezczeszczeniem ludzkiego ciała (Rz 1,24).

Praktyki homoseksualne jako grzech przeciw Prawu i Prawdzie św. Paweł łączy (podobnie jak jest to $\mathrm{w} \mathrm{Rdz}$ 19) z brakiem prawdziwego poznania źródła Prawa i Prawdy, czyli Boga, przez ludzi, do których nie dotarło jeszcze światło Objawienia, jakkolwiek winni oni rozpoznać Boga i uznać Go na drodze tzw. objawienia naturalnego wpisanego w stworzony świat, a dostępnego dla wszystkich, także dla pogan (por. Rz 1,18-32). Nie rozpoznawszy Stworzyciela, oddawali cześć „obrazom i rzeźbom” ludzi i zwierząt (Rz 1,20-25). Nie zrozumieli istotnej różnicy między stworzeniami a Stwórcą, pomieszali rzeczywistości odmienne, stąd fałszywa religia (idolatria). „Ten brak rozumu - według Pawła - ma swoje konsekwencje natury antropologicznej, przede wszystkim wypaczenia natury seksualnej (distorsioni sessuali)"

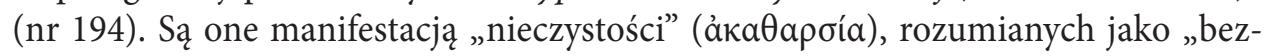
czeszczenie własnych ciał", a wszystko to objawia się w emblematyczny sposób w homoseksualnych praktykach żeńskich i męskich. Zamiana wiary w Boga prawdziwego w bałwochwalstwo ma skutek w postaci „,zmiany w relacjach seksualnych”, i z tego też powodu określone są one jako „przeciwne naturze” (Rz 1,26). Papieska Komisja Biblijna wyjaśnia to słowami:

Określenie to winno być rozumiane jako wskazanie na coś, co kontrastuje z rzeczywistością stworzoną, a mianowicie rzeczywistością ciał obdarzonych różnorodnymi cechami płciowymi (corpi sessuati, che hanno in loro stessi una differenza) i celowością, która nie jest rozpoznawana. Co więcej, tej różnorodności i tej celowości wpisanej w ciało mężczyzny i ciało kobiety nie okazuje się posłuszeństwa, gdy się praktykuje relacje seksualne z osobami tej samej płci (nr 194) ${ }^{25}$.

Zob. Aletti, God's Justice in Romans, 62-65; Kowalski, „Apokaliptyczny gniew Boga”, 232-233.

Pawłowe wyrażenie „przeciwne naturze” ma przede wszystkim sens teologiczny i oznacza działania sprzeczne z porządkiem stworzenia, które przenika boski Logos - ten sam, który przenika prawo Boże. Zgodne $\mathrm{z}$ „naturą" jest natomiast to, co wpisuje się w Boży plan stworzenia, w jego celowość - w tym przypadku w stworzenie człowieka jako mężczyzny i kobiety, powołanych do przekazywania życia. Dla św. Pawła „natura” nie oznacza po prostu zwyczaju czy panującej w danym okresie i w konkretnym środowisku normy kulturowej, ale ma rangę prawa Bożego o charakterze uniwersalnym, które apostoł także w innych tekstach aplikuje do całej ludzkości, a nie tylko do adresatów swoich listów. W Rz 1,26-28 pojęcie „natura” obejmuje ten wymiar porządku stworzenia, jakim jest właściwe dla człowieka rozróżnienie na płeć męską i żeńską. Por. Brooten, Love Between Women, 272-280; Hays, „Relations Natural and Unnatural”, 192-194; Malick, „The Condemnation of Homosexuality”, 335; Moo, The Epistle to the Romans, 114-115; Mueller, Homosexuality, Scripture, and the Church, 25; Springett, Homosexuality in History, 129. 
Według apostoła Pawła stosunki homoseksualne manifestują nieuporządkowane namiętności, gdzieindziej określone jako „żądze cielesne” (por. Ga 5,16-17; Ef 2,3). Zostają one dalej zakwalifikowane jako „bezecne namiętności” (Rz 1,26), „bezwstyd” (Rz 1,27), „aberracja” (Rz 1,27). W ten sposób Paweł, aktualizując nauczanie Księgi Kapłańskiej, po pierwsze znosi sankcję za te akty w postaci kary śmierci, choć pisze dalej o śmierci wiecznej, jaką one sprowadzają. A to oznacza głęboką zmianę perspektywy: z jurydycznej i doczesnej na soteriologiczną i wieczną; po drugie widzi rzeczywiste wykroczenie przeciw logice zawartej w stworzeniu, a zatem przeciw Rozumowi (Logosowi - por. J 1,1-3) ${ }^{26}$, a co za tym idzie także przeciw własnemu rozumowi. Dlatego widzi w tych aktach przejaw głupoty pojmowanej jako świadome wypaczanie prawdy stworzenia i sprzeniewierzanie się jej, oparte na zafałszowanym jej obrazie ${ }^{27}$. Z tej racji czytamy w dokumencie: „«Dlatego to wydał ich Bóg na pastwę bezecnych namiętności [...] tak że na samych sobie ponoszą zapłatę należną za zboczenie» (Rz 1,26-27). Tak więc człowiek winien widzieć w życiu seksualnym, które nie uznaje «naturalnych» różnic, symptom wypaczenia prawdy" (nr 194) ${ }^{28}$.

26 W komentarzu do J 1,1 Benedykt XVI pisze, że ów boski Logos, który był na początku, „oznacza zarówno Rozum, jak i Słowo - Rozum, który jest twórczy i zdolny do samokomunikowania, właśnie jako rozum”. Zob. Scott, Przymierze i komunia, 49.

27 Szczegółowy wywód Pawła pozwala zobaczyć całą głębię tego znieprawienia rozumu (i sumienia - „zaćmionego serca”), które doprowadza człowieka do czegoś więcej niż głupota - do szaleństwa: „Albowiem gniew Boży objawia się z nieba na wszelką bezbożność i nieprawość tych ludzi, którzy przez nieprawość nakładają prawdzie pęta. To bowiem, co o Bogu można poznać, jawne jest wśród nich, gdyż Bóg im to ujawnił. Albowiem od stworzenia świata niewidzialne Jego przymioty - wiekuista Jego potęga oraz bóstwo - stają się widzialne dla umysłu przez Jego dzieła, tak że nie mogą się oni wymówić od winy, ponieważ, choć Boga poznali, nie oddali Mu czci jako Bogu ani Mu nie dziękowali, lecz znikczemnieli w swoich myślach i zaćmione zostało bezrozumne ich serce. Podając się za mądrych, stali się głupimi”

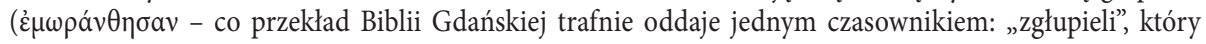
wyraża rzeczywistość bardziej cało-osobowo [obejmuje także szaleńcze zachowania], a nie tylko w odniesieniu do samego rozumu) (Rz 1,18-22). Szczegółową analizę pojęć, które św. Paweł aplikuje do opisania żeńskich i męskich relacji homoseksualnych w Rz 1,26-27 przeprowadza M. Kowalski („Odrzucenie praw Stwórcy", 256-264).

28 Akty homoseksualne są sprzeczne nie tylko z Prawem (Torą - por. Rdz 1,26-27; Kpł 18,22; 20,23 - co jest bardzo ważne dla wierzących Żydów), ale także z rozumem, którym kierują się przede wszystkim poganie, odkrywający boski Logos porządkujący stworzony świat. Akty te manifestacją znikczemnienia ludzkiego rozumu: „Boga poznali, nie oddali Mu czci jako Bogu ani Mu nie dziękowali, lecz znikczemnieli w swoich myślach i zaćmione zostało bezrozumne ich serce. Podając się za mądrych, stali się głupimi. I zamienili chwałę niezniszczalnego Boga na podobizny i obrazy śmiertelnego człowieka, ptaków, czworonożnych zwierząt i płazów. Dlatego wydał ich Bóg poprzez pożądania ich serc na łup nieczystości, tak iż dopuszczali się bezczeszczenia własnych ciał. Prawdę Bożą przemienili oni w kłamstwo i stworzeniu oddawali cześć, i służyli jemu, zamiast służyć Stwórcy, który jest błogosławiony na wieki. Amen” (Rz 1,21-25). Jak widać Apostoł Narodów kieruje swe nauczanie zarówno do pogańskich, jak i żydowskich odbiorców. Relacje homoseksualne, podobnie jak grzechy opisane w Rz 1,29-31, są efektem idolatrii, która wynika z radykalnego zepsucia procesu poznawania Boga-Stwórcy z analizy całego stworzenia. W kontekście Rz 1,26-27 św. Paweł nie prezentuje wąskiego, kultycznego rozumienia idolatrii, ale głęboko uniwersalne - powiązane z właściwą dla każdego człowieka zdolnością analizy skutkowo-przyczynowej i odkrywaniem powszechnie obowiązującej Prawdy. 


\section{HENRYK WITCZYK}

W dalszej części swego wykładu na temat stosunków między osobami tej samej płci św. Paweł wyciąga wnioski natury społecznej. Brak poznania prawdziwego Boga prowadzi w życiu społecznym do zachowań niszczących porządek i do przemocy. Dotyczy to wszystkich relacji interpersonalnych, także małżeństwa i rodziny (por. 1 Kor 11,2-6) ${ }^{29}$. W Rz 1,29-31 Paweł podaje całą ich listę, na podstawie której poznajemy, w jak ciężkiej sytuacji znajduje się świat widziany oczami apostoła oświeconego światłem Prawa i Ewangelii. Dochodzi nawet do zuchwałego odwrócenie do góry nogami najważniejszych wartości dobra i zła: „Oni to, mimo że dobrze znają wyrok Boży, iż ci, którzy się takich czynów dopuszczają, winni są śmierci, nie tylko je popełniają, ale nadto chwalą tych, którzy to czynią" (Rz 1,32). Przyczyną główną tego odwrócenia jest kłamstwo dotyczące Boga Stworzyciela: ludzie ci chcą samych siebie uznawać za bogów (idąc za podszeptem kusiciela z Rdz 3) i nazywać dobrem to, co jest wypaczeniem dzieła Stwórcy.

Umieszczając grzechy żeńskiego i męskiego homoseksualizmu pośród innych grzechów (tak w Rz 1,18-32, jak i w 1 Kor 6,8-10 oraz 1 Tm 1,9-10) św. Paweł ich nie relatywizuje. Przeciwnie, sugeruje wyraźnie, że są one mocno powiązane z powszechnym zepsuciem jednostki oraz społeczności, do którego właśnie prowadzą jako jedna z głównych przyczyn. Według starożytnych filozofów, gdyby nie były one przezwyciężane przez cnoty, mogłyby nawet doprowadzić do destrukcji struktur społecznych, zaniku porządku moralnego i zniszczenia rodziny ${ }^{30}$. Odpowiada za to tkwiące w nich hołdowanie przyjemności, odrzucenie Bożych praw oraz rozumu odkrywającego uniwersalną prawdę i celowość dotyczącą stworzenia.

\section{Konkluzja}

Przytaczana przez mnie w powyższych paragrafach medialna krytyka dokumentu Czym jest człowiek? bodaj najlepiej uzasadnia zawarty w nim apel o inteligentną interpretację tekstów Pisma Świętego i jego ponadczasowego orędzia antropologiczno-zbawczego. Ma to być interpretacja wolna od fundamentalistycznej i powierzchownej dosłowności, żonglującej wyrwanymi z kontekstu, pojedynczymi tekstami czy nawet fragmentami świętego tekstu, w ich oderwaniu od całości przesłania Biblii oraz jej rozumienia obecnego już w tradycji religijnej ludu Przymierza (np. prorocy, mędrcy) i w Kościele apostolskim, bez uwzględniania ich gatunków literackich i szerokiego - a nie wybiórczego - ich kulturowego zakorzenienia w określonym

29 Ważne implikacje zachowywania prawa Bożego w odniesieniu do relacji między mężczyzną i kobietą w zakresie kształtu małżeństwa i rodziny analizuje M. Kowalski („Między darem Bożym a konstruktem społecznym", 59-104).

30 Zob. Himbaza - Schenker - Edart, The Bible on the Question of Homosexuality, 99-105; Kowalski, „Odrzucenie praw Stwórcy”, 273-275; Gagnon, The Bible and Homosexual Practice, 284-289. 
miejscu i czasie, które nie zagrażają ponadczasowemu przesłaniu Pisma Świętego, ale pozwalają je głębiej rozumieć w ich uniwersalnym znaczeniu i owocniej aplikować w Kościele i świecie współczesnym. W dokumencie Papieskiej Komisji Biblijnej przywołane zostały wszystkie teksty biblijne, w których bezpośrednio podejmowana jest kwestia żeńskich i męskich praktyk homoseksualnych. Wszystkie one bez wyjątku wyrażają najpierw stanowczy sprzeciw wobec tych aktów, co w dokumencie zostało wyraźnie zaznaczone przez tytuł paragrafu: „Relacje transgresywne”. Obok homoseksualizmu analizowane są $\mathrm{w}$ nim takie wykroczenia przeciw ustanowionemu przez Stwórcę związkowi małżeńskiemu, jak kazirodztwo, cudzołóstwo i prostytucja (nr 181-195). Akty homoseksualne są najpierw przedstawiane jako radykalnie sprzeczne z prawdą dotyczącą stworzenia człowieka mężczyzną i kobietą oraz ściśle związaną z tą prawdą celowością tak właśnie zróżnicowanego stworzenia. Są one widziane jako czynniki destrukcyjne zarówno w odniesieniu do samych osób powołanych do życia w monogamicznej i heteroseksualnej relacji miłości, jak i prokreacji gwarantującej rozwój dziejów zbawienia i „panowania” człowieka na ziemi. Następnie akty homoseksualne są - zarówno w optyce ST, jak i NT - dowodem „znikczemnienia” ludzkiego rozumu, który świadomie wypacza najgłębszą prawdę i logikę (boski i ludzki sens) stworzenia. Z kolei surowo zakazywane przez Torę - i to w najbardziej podstawowym prawodawstwie dotyczącym „czystości” i „świętości” wyznawcy Jedynego Boga (Księga Kapłańska) - są osądzane jako praktyki niszczące tę „świętość” i „czystość”, czyli wykluczające wierzącego ze wspólnoty z Bogiem i ze wspólnoty kultowej ludu Przymierza. Dla podkreślenia wagi tej destrukcji Prawodawca nakłada sankcję w postaci kary śmierci. Kościół apostolski widzi w aktach homoseksualnych - oprócz wymienionych wyżej faktorów niszczycielskich - czyny, które są bezczeszczeniem ciała chrześcijanina. Od chwili chrztu jest ono świątynią Ducha Świętego i żywą cząstką Ciała Chrystusa. Bezczeszczenie tej świątyni nie tylko pozbawia go świętej Obecności Ducha - Miłości, ale także oddala od zmartwychwstałego Chrystusa i Jego Kościoła - i dlatego jest grzechem przeciw Bogu w Trójcy Osób, i jako taki łamie Przymierze z Nim i ludem nowego i wiecznego Przymierza (por. Ap 22,11.15).

Z powyższej analizy dokumentu Papieskiej Komisji Biblijnej oraz jego medialnych prezentacji rodzi się apel, a nawet wezwanie do całościowej, a nie wyrywkowej lektury. Co więcej, jak to podkreślono w zakończeniu tegoż dokumentu, niezwykle ważne, wręcz konieczne dla jego poprawnego zrozumienia, jest sięganie do tekstów Pisma Świętego, które w dokumencie przywoływane są jedynie w nawiasach. Wówczas każdy uważny czytelnik będzie mógł w dużej mierze samodzielnie poznać, jaki jest plan Boży i prawda Boża dotycząca człowieka jako mężczyzny i kobiety. Prawda ta wpisana jest także w logikę stworzenia.

Każdy, kto przybliża w mediach naukę zawartą w Biblii i dokumencie Kościoła na ten temat, ponosi odpowiedzialność za jej prezentację w sposób wolny od wypaczeń, 
manipulacji czy niedomówień. Do takiej odpowiedzialności za osoby o inklinacjach homoseksualnych bądź osoby, zwłaszcza młode, wystawiane na próby przez zepsute środowiska, bądź kuszone mirażami wolności od prawdy wzywa nas Ewangelia i dokumenty Magisterium Kościoła. Jest to w gruncie rzeczy - jak wynika z powyższych analiz tekstów Pisma Świętego - odpowiedzialność i troska o ich (i każdego z prezenterów lub interpretatorów) szczęście doczesne i wieczne zbawienie.

Tylko pełna i dogłębna interpretacja wymienionych w dokumencie (i jeszcze innych, w mniejszym lub większym stopniu paralelnych tekstów Pisma Świętego) pomoże moralistom, pastoralistom, duszpasterzom i wiernym świeckim w podejmowaniu zbawczej troski o osoby dopuszczające się praktyk homoseksualnych, w obronie kultury i antropologii chrześcijańskiej przed nacierającą ideologią radykalnie sprzeczną z prawdą Objawienia i prawdą rozumu, odczytującego dzieło i zamysł Boga Stwórcy dotyczący mężczyzny i kobiety.

\section{Bibliografia}

Aletti J-N., God's Justice in Romans. Keys for Interpretating the Epistle to the Romans (Subsidia Biblica 37; Rome: Gregorian \& Biblical Press 2010).

Bailey, K.E., „Paul's Theological Foundation for Human Sexuality. 1 Cor 6:9-20 in the Light of Rhetorical Criticism", Theological Review 3/1 (1980) 27-41.

Brooten, B.J., Love Between Women. Early Christian Responses to Female Homoeroticism (The Chicago Series on Sexuality, History, and Society; Chicago, IL: University of Chicago Press 1996). „La Chiesa chiede «attenzione pastorale» alle unioni omosessuali. La Pontificia Commissione biblica ha realizzato uno studio antropologico di 300 pagine sul testo cristiano: «La relazione erotica omo non va condannata» (17.12.2019)", La Repubblica, https://www.repubblica .it/cronaca/2019/12/17/news/e_la_chiesa_chiede_attenzione_pastorale_alle_unioni_ omosessuali-243723693/ [dostęp: 27.05.2021].

Ciampa, R.E. - Rosner, B.S., The First Letter to the Corinthians (The Pillar New Testament Commentary; Grand Rapids, MI - Cambridge, U.K.: Eerdmans 2010).

Davis, E.F., „Reasoning with Scripture”, Anglican Theological Review 90 (2008) 513-519.

DeYoung, J.B., „The Meaning of 'Nature' in Romans 1 and Its Implications for Biblical Proscriptions of Homosexual Behavior", Journal of the Evangelical Theological Society 31/4 (1988) 429-441.

Esler, P.F., „The Sodom Tradition in Romans 1:18-32”, Biblical Theology Bulletin 34/1 (2004) 4-16. Fee, G.D., The First Epistle to the Corinthians (New International Commentary on the New Testament; Grand Rapids, MI - Cambridge, U.K.: Eerdmans 2014).

Fredrickson, D.E., „Natural and Unnatural Use in Romans 1:24-27. Paul and the Philosophic Critique of Eros", Homosexuality, Science, and the "Plain Sense" of Scripture (red. D.L. Balch) (Grand Rapids, MI: Eerdmans 2000) 197-222.

Gagnon, R.A.J., The Bible and Homosexual Practice (Nashville, TN: Abingdon 2002). 
Gnuse, R.K., „Seven Gay Texts. Biblical Passages Used to Condemn Homosexuality”, Biblical Theology Bulletin 45/2 (2015) 68-87.

Gross, W., „Gen 1,26.27; Gen 9,6: Statue oder Ebenbild Gottes? Aufgabe und Würde des Menschen nach dem hebräischen und dem griechischen Wortlaut", Jahrbuch für Biblische Theologie 15 (2000) 11-38.

Guzik, D., „Genesis 19 - Sodoma and Gomarrah”, Enduring Word Bible Commentary, https:// enduringword.com/bible-commentary/genesis-19/ [dostęp: 27.05.2021].

Hahn, S.W., Przymierze i komunia. Teologia biblijna papieża Benedykta XVI (Kraków: Esprit 2021).

Hays, R.B., „Relations Natural and Unnatural. A Response to J Boswell's Exegesis of Rom 1”, Journal of Religious Ethics 14/1 (1986) 184-215.

Himbaza, I. - Schenker, A. - Edart, J.-B., The Bible on the Question of Homosexuality, Homosexuality (Washington, D.C.: Catholic University of America Press 2012).

Horvat, J. (red.), W obronie praw wyższych. Dlaczego mamy przeciwstawiać się legalizacji związków homoseksualnych? (Kraków: Stowarzyszenie Kultury Chrześcijańskiej im. ks. Piotra Skargi 2009).

Janowski, B., „Die lebendige Statue Gottes. Zur Anthropologie der priesterlichen Urgeschichte”, Gott und Mensch im Dialog. Festschrift für Otto Kaiser zum 80. Geburtstag (red. M. Witte) (Beihefte zur Zeitschrift für die alttestamentliche Wissenschaft 345/1; Berlin - New York: De Gruyter 2004) 183-214.

Jaśkiewicz, S., „Złe czyny mieszkańców Sodomy (Rdz 19,1-11) w interpretacji św. Augustyna”, Verbum Vitae 39/1 (2021) 353-368.

Klän, W., „Das Gesammtdasein Menschlichen Geschlechts mit allen den Geschichtlich Gewordenen Zuständen. Schöpfungsordnung und Lebensverhältnisse", Lutherische Theologie Und Kirche 27/1-2 (2003) 91-105.

Kowalski, M., „Apokaliptyczny gniew Boga i jego miejsce w Ewangelii Pawła (Rz 1,18-32)”, Verbum Vitae 33 (2018) 203-249.

Kowalski, M., „Honor i wstyd, prawo naturalne oraz Pisma. Podstawy Pawłowej argumentacji na temat żeńskich i męskich relacji homoseksualnych w Rz 1,26-27", Verbum Vitae 39/1 (2021) 223-254.

Kowalski, M., „Katalogi wad, Dekalog i relacje homoseksualne w 1 Kor 6,9-10 oraz 1 Tm 1,8-10”, Verbum Vitae 39/1 (2021) 281-306.

Kowalski, M., „Odrzucenie praw Stwórcy i relacje homoseksualne w Rz 1,26-27, Verbum Vitae 39/1 (2021) 255-280.

Kowalski, M., „Między darem Bożym a konstruktem społecznym. Wczesnochrześcijańskie rozumienie płciowości na podstawie 1 Kor 11,2-16", Biblica et Patristica Thorunensia 13/1 (2020) 59-104.

Lemański, J., „Człowiek jako mężczyzna i kobieta. Fundamenty antropologii biblijnej, ich źródła i konsekwencje”, Verbum Vitae 39/1 (2021) 97-118.

Malick, D.E., „The Condemnation of Homosexuality in Romans 1:26-27”, Bibliotheca Sacra $150 / 3$ (1993) 327-340.

Malina, B.J. - Pilch, J.J., Social-Science Commentary on the Letters of Paul (Minneapolis, MN: Fortress 2006). 


\section{HENRYK WITCZYK}

May, A.S., The Body for the Lord. Sex and Identity in 1 Corinthians 5-7 (Journal for the Study of the New Testament Supplement Series 278; London: Clark 2004).

Moo, D.J., The Epistle to the Romans (New International Commentary on the New Testament; Grand Rapids, MI: Eerdmans 1996).

Morschauser, S., „'Hospitality', Hostiles and Hostages. On the Legal Background to Genesis 19:1-9", Journal for the Study of the Old Testament 27/4 (2003) 461-485.

Mueller, E., Homosexuality, Scripture, and the Church (Silver Spring, MD: Biblical Research Institute 2010).

Muszytowska, D., „Kwestia homoseksualizmu w Listach Powszechnych i w Apokalipsie św. Jana”, Verbum Vitae 39/1 (2021) 307-322.

Napora, K., „'Wąż', ‘życie’, czy 'matka wszystkiego, co żyje’? Znaczenie imienia חָi i jego funkcja w Rdz 3", Niewiastę dzielna kto znajdzie? (Prz 31,10). Rola kobiet w biblijnej historii zbawienia (red. A. Kubiś - K. Napora) (Analecta Biblica Lublinensia 14; Lublin: Wydawnictwo KUL 2016) 15-27.

Napora, K. „«Mieszkańcy Sodomy byli źli...» (Rdz 13,13). Na czym polegał występek mieszkańców Sodomy", Verbum Vitae 39/1 (2021) 119-136.

Napora, K., „Odpowiednia dla niego pomoc? Kobieta w Rdz 1-2”, Sympozjum 21 (2017) 33-48.

Neumann-Gorsolke, U., Herrschen in den Grenzen der Schöpfung. Ein Beitrag zur alttestamentlichen Anthropologie am Beispiel von Psalm 8, Genesis 1 und verwandten Texten (Wissenschaftliche Monographien zum Alten und Neuen Testament 101; Neukirchen: Neukirchener Verlag 2004).

Parker, S., „The Hebrew Bible and Homosexuality”, Quarterly Review 11 (1991) 4-19.

Pontificia Commissione Biblica, „Che cos'e l'uomo?” (Sal 8,5). Itinerario antropologico (Città del Vaticano: Libreria Editrice Vaticana 2019); tł. polskie H. Witczyk: „Czym jest człowiek?” (Ps 8,5). Zarys antropologii biblijnej (Kielce: Jedność 2020).

Springett, R.M., Homosexuality in History and the Scriptures. Some Historical and Biblical Perspectives on Homosexuality (Washington, D.C.: Biblical Research Institute 1988).

Strzałkowska, B., „Homoseksualizm w prawodawstwie biblijnego Izraela”, Verbum Vitae 39/1 (2021) 137-162.

Suchy, J., „Czyńcie sobie ziemię poddaną, panujcie nad zwierzętami”, Zeszyty Naukowe KUL 36/1-4 (1993) 13-23.

Szymik, S., „ «Czyńcie sobie ziemię poddaną» ( $\mathrm{Rdz} 1,28)$. Cywilizacyjny postęp ludzkości w świetle Rdz 1-11", Verbum Vitae 31 (2017) 21-44.

Towner, P.H., The Letters to Timothy and Titus (New International Commentary on the New Testament; Grand Rapids, MI: Eerdmans 2006).

Twardziłowski, T., „The Command to Rule over the Creation (Gen 1:26-28) in the Ecological Hermeneutics of the Bible", Collectanea Theologica 90/5 (2020) 9-32.

White, L.J., „Does the Bible Speak about Gays or Same-Sex Orientation? A Test Case in Biblical Ethics", Biblical Theology Bulletin 25/1 (1995) 14-23.

Wright, D.F., „Homosexuals or Prostitutes? The Meaning of AP $\Sigma$ ENOKOITAI (1 Cor. 6:9, 1 Tim. 1:10)”, Vigiliae Christianae 38/2 (1984) 125-153.

Wright, D.F., „Translating AP¿ENOKOITAI (1 Cor 6:9, 1 Tim 1:10)”, Vigiliae Christianae 41/4 (1987) 396-398.

Yarbrough, R.W., The Letters to Timothy and Titus (Pillar New Testament Commentary; Grand Rapids, MI - London: Eerdmans 2018). 